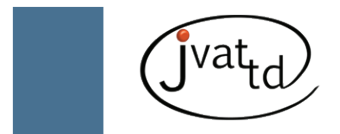

\title{
Epidemiological profile of snakebites in Rio de Janeiro, Brazil, 2001-2006
}

\author{
Machado C (1), Bochner R (2), Fiszon JT (3)
}

(1) Vital Brazil Institute (IVB), Niterói, Rio de Janeiro State, Brazil; (2) Institute for Communication and Scientific and Technological Information on Health (ICICT), Oswaldo Cruz Foundation (Fiocruz), Rio de Janeiro, Rio de Janeiro State, Brazil; (3) Sergio Arouca National School of Public Health (ENSP), Oswaldo Cruz Foundation (Fiocruz), Rio de Janeiro, Rio de Janeiro State, Brazil.

\begin{abstract}
All snakebites registered in Rio de Janeiro state, Brazil, between 2001 and 2006 were analyzed. Of these, the snake species involved was identified in 2,431 cases, most of which were caused by Bothrops $(2,347)$. Most victims were male $(78.4 \%)$ and the age group most frequently attacked was between 20 and 39 years (38.4\%). As for severity, 1,118 (45.9\%) were classified as minor, 748 (30.7\%) as moderate, and 209 $(8.6 \%)$ as severe. Progression towards complete cure occurred in 1,567 patients; 39 had sequelae; three died; and clinical outcomes were not monitored in 822 cases. The time between bite and first medical attention was less than three hours in $74.6 \%$ of cases. Most occurred in municipalities with vast areas of preserved Atlantic Forest: Angra dos Reis (208), Rio de Janeiro (197), Parati (186), Teresópolis (134), and Petrópolis (110). Accident frequency was highest between November and April, in which the daily average is practically twice that observed in other months. Although results show that Rio de Janeiro state has a good level of medical care, it could be improved by creating multidisciplinary teams that include doctors, biologists, and nurses. The Vital Network for Brazil helps to promote a stimulating environment for this type of training, with both traditional courses and distance learning. Training hours must be increased to improve the skills of professionals responsible for victim care.
\end{abstract}

Key words: snakebites, envenomation, snake bite epidemiology, information systems.

\section{INTRODUCTION}

Accidents caused by venomous snakes are a serious public health issue in tropical countries, especially in Latin America. It is estimated that $2,500,000$ accidents with venomous snakes occur annually in the world; approximately 125,000 are lethal (1-9).

The Brazilian Health Department (10) estimates that approximately 26,000 snakebites occur each year in Brazil. According to Lira-daSilva et al. (11), this is an underestimate because of inadequacies in data collection, and a large insufficiency in the number of notifications. Although the majority of snakebites occur in northern Brazil, most records come from the south and southeast regions, where most of the population is concentrated, and where the quality of health care and information systems are much better $(12,13)$.

Rural areas are more affected by snakebites, presenting high morbidity and mortality rates. This is due to higher exposure of the population to risk areas, and to difficulties in accessing health centers that can provide snake antivenom, the only specific treatment for these accidents. Numerous victims suffer permanent consequences due to the necrotic action of venoms. And there are also psychological consequences. The economic impact of these accidents is considerable, because most victims are young (14).

The information on number of accidents 
per region, types of venom, deaths and the consequences of accidents are essential for evaluating the problem and developing public policies aimed at reducing the number of accidents, and improving medical help for victims. The importance of recording snakebites has been a concern since Vital Brazil's time (1865-1950) (15). The first epidemiological study on ophidism in Brazil was made in 1901 by Vital Brazil: he collected the number of deaths from venomous snakebites in São Paulo state (SP). Since then, little progress has been made on the knowledge of ophidism in Brazil, because information on accidents was scarce and recording not mandatory.

Before the 1980s, studies presenting significant information and detailed epidemiological data were published by Penteado (16), Amaral (17), Barroso (18) and Fonseca (19). Due to shortages in serum production in 1985, the Brazilian Ministry of Health stated that notification of snakebites were mandatory from 1986 onward. Later, its inclusion in a health information system for episodic accidents became mandatory as well. Since then, it became possible to follow the evolution of these accidents. More and more epidemiological studies on snakebites have been conducted in Brazil, especially at a regional level (13, 20-40).

The small amount of research on snakebite epidemiology in Rio de Janeiro state, Brazil, justifies the analysis of the available information, and comparison of subsequent results with existing studies from the rest of the country.

\section{MATERIALS AND METHODS}

On November 28, 2010, information held by the Notifiable Diseases Information System (SINAN) on snakebites that occurred in Rio de Janeiro state between 2001 and 2006 was collected. The study period is explained by the following: 2001 was the first year in which information was available online, and 2006 was the most recent year in which information appears consolidated, without the need for further revision. Only accidents involving aggressive venomous snakes were recognized and taken into account. Cases in which the snake was identified as non-venomous were ignored.

In order to analyze the monthly distribution of accidents in each period, independent of the number of days in the month, a daily average for accidents was established using the following formula: number of accidents recorded during a month divided by number of days in that month.

Even though only secondary data provided by SINAN was analyzed without identifying any of the victims, the present study was submitted to and approved by the Ethics Committee on Human Research,of Joaquim Venancio Polytechnic Health School, Oswaldo Cruz Foundation (Fiocruz) (protocol number 2011/0128).

\section{RESULTS}

According to SINAN, 2,431 snakebites were registered in Rio de Janeiro state between 2001 and 2006. Table 1 shows the distribution of these accidents by snake genera and age group, gender, and education level of victims. It also indicates elapsed time between the accident and first medical attention, and clinical data on the severity and evolution of the envenomation. Figure 1 shows the municipalities with higher number of notifications. In the period, more than one hundred accidents occurred in the following cities: Angra dos Reis (208 cases), the capital Rio de Janeiro (197), Parati (186), Teresópolis (134), and Petrópolis (110). Municipalities where the incidence of snakebites was higher were: Trajano de Moraes (115.7 per 100,000 inhabitants), Parati (97.5), Varre-sai (71.6), and Duas Barras (71.3).

The 20 to 39 years age group had the highest number of victims, 934 cases; 760 males (81.3\%), 173 females (18.5\%); in only one case the victim gender was not specified (Figure 2).

Accidents were more frequent between November and April (Figure 3). In the figure, it is possible to observe that increase in daily average of accidents follows a seasonal rhythm, with values doubling between 2002 and 2006.

\section{DISCUSSION}

The predominance of Bothrops snakebites (96.5\%) recorded in Rio de Janeiro state reflects the national situation (10). This pattern has also been described for several states including Amazonas, Amapá, Roraima, Ceará, Sergipe, Bahia, Paraíba, and Goiás (13, 22, 31-33, 35, 3739).

Nearly $35 \%$ of all cases in Rio de Janeiro state were concentrated in five regions: Angra 
Table 1. Distribution of snakebites by snake genera; age group, gender, and education level of victims; elapsed time between accident and first medical attention; and case classification and evolution (Rio de Janeiro state, 2001 to 2006)

\begin{tabular}{|c|c|c|c|c|c|}
\hline \multirow[b]{2}{*}{ Variable } & \multicolumn{4}{|c|}{ Genus of the snake } & \multirow[b]{2}{*}{ Total } \\
\hline & Bothrops & Crotalus & Micrurus & Lachesis & \\
\hline \multicolumn{6}{|l|}{ Victim's age group } \\
\hline$<1$ year & 20 & - & - & - & 20 \\
\hline $1-4$ & 30 & 2 & - & - & 32 \\
\hline $5-9$ & 95 & - & 2 & - & 97 \\
\hline $10-14$ & 174 & 1 & - & - & 175 \\
\hline $15-19$ & 181 & 3 & 3 & 1 & 188 \\
\hline $20-39$ & 896 & 32 & 4 & 2 & 934 \\
\hline $40-59$ & 682 & 21 & 2 & 2 & 707 \\
\hline $60-64$ & 104 & 2 & 2 & - & 108 \\
\hline $65-69$ & 86 & 2 & - & - & 88 \\
\hline $70-79$ & 68 & 2 & - & - & 70 \\
\hline 80 and over & 10 & 1 & - & - & 11 \\
\hline Unknown & 1 & - & - & - & 1 \\
\hline \multicolumn{6}{|l|}{ Victim's gender } \\
\hline Male & 1844 & 47 & 10 & 4 & 1905 \\
\hline Female & 498 & 19 & 3 & 1 & 521 \\
\hline Unknown & 5 & - & - & - & 5 \\
\hline \multicolumn{6}{|c|}{ Education level of the victim } \\
\hline None & 140 & 4 & 1 & - & 145 \\
\hline $1-3$ years & 323 & 5 & - & - & 328 \\
\hline 4-7 years & 485 & 11 & 3 & 3 & 502 \\
\hline $8-11$ years & 126 & 7 & 1 & - & 134 \\
\hline 12 or more years & 35 & - & 1 & - & 36 \\
\hline Does not apply & 115 & 2 & 2 & - & 119 \\
\hline Unknown & 1123 & 37 & 5 & 2 & 1167 \\
\hline \multicolumn{6}{|c|}{ Elapsed time between the bite and first medical care } \\
\hline $0-1$ hours & 885 & 19 & 8 & 2 & 914 \\
\hline 1-3 hours & 871 & 24 & 2 & 2 & 899 \\
\hline 3-6 hours & 194 & 8 & 1 & 1 & 204 \\
\hline $6-12$ hours & 62 & 2 & - & - & 64 \\
\hline 12 or more hours & 51 & 3 & 1 & - & 55 \\
\hline Unknown & 284 & 10 & 1 & - & 295 \\
\hline \multicolumn{6}{|l|}{ Classification of the case } \\
\hline Minor & 1083 & 27 & 6 & 2 & 1118 \\
\hline Moderate & 726 & 20 & 1 & 1 & 748 \\
\hline Severe & 193 & 14 & 2 & - & 209 \\
\hline Unknown & 345 & 5 & 4 & 2 & 356 \\
\hline \multicolumn{6}{|l|}{ Evolution of the case } \\
\hline Cure & 1514 & 41 & 9 & 3 & 1567 \\
\hline Cure with sequelae & 39 & - & - & - & 39 \\
\hline Death & 2 & 1 & - & - & 3 \\
\hline Unknown & 792 & 24 & 4 & 2 & 822 \\
\hline Total & 2347 & 66 & 13 & 5 & 2431 \\
\hline
\end{tabular}

Source: MS/SVS/SINAN 


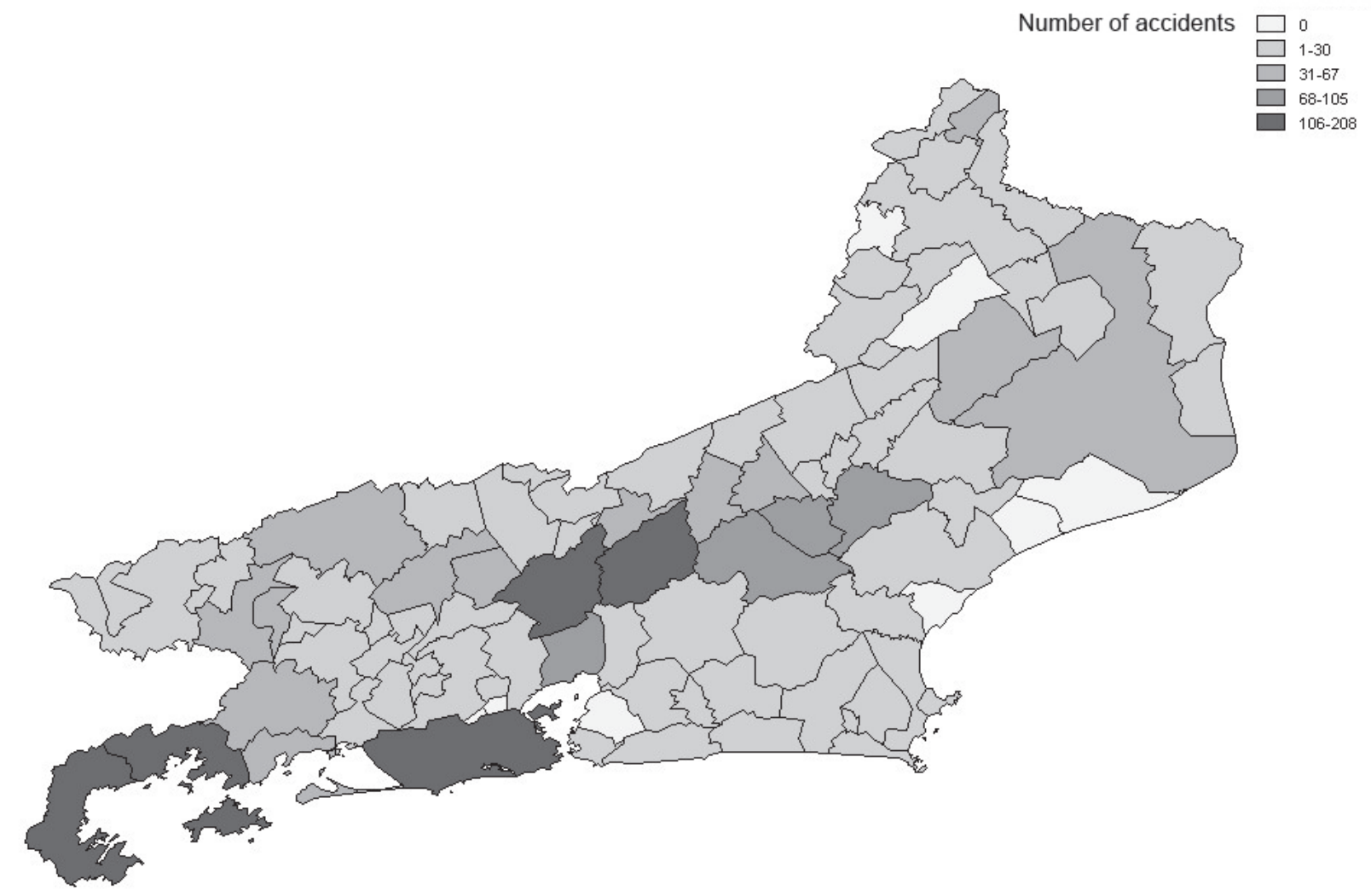

Figure 1. Spatial distribution of snakebites in Rio de Janeiro state between 2001 and 2006 (source: MS/SVS/ SINAN).

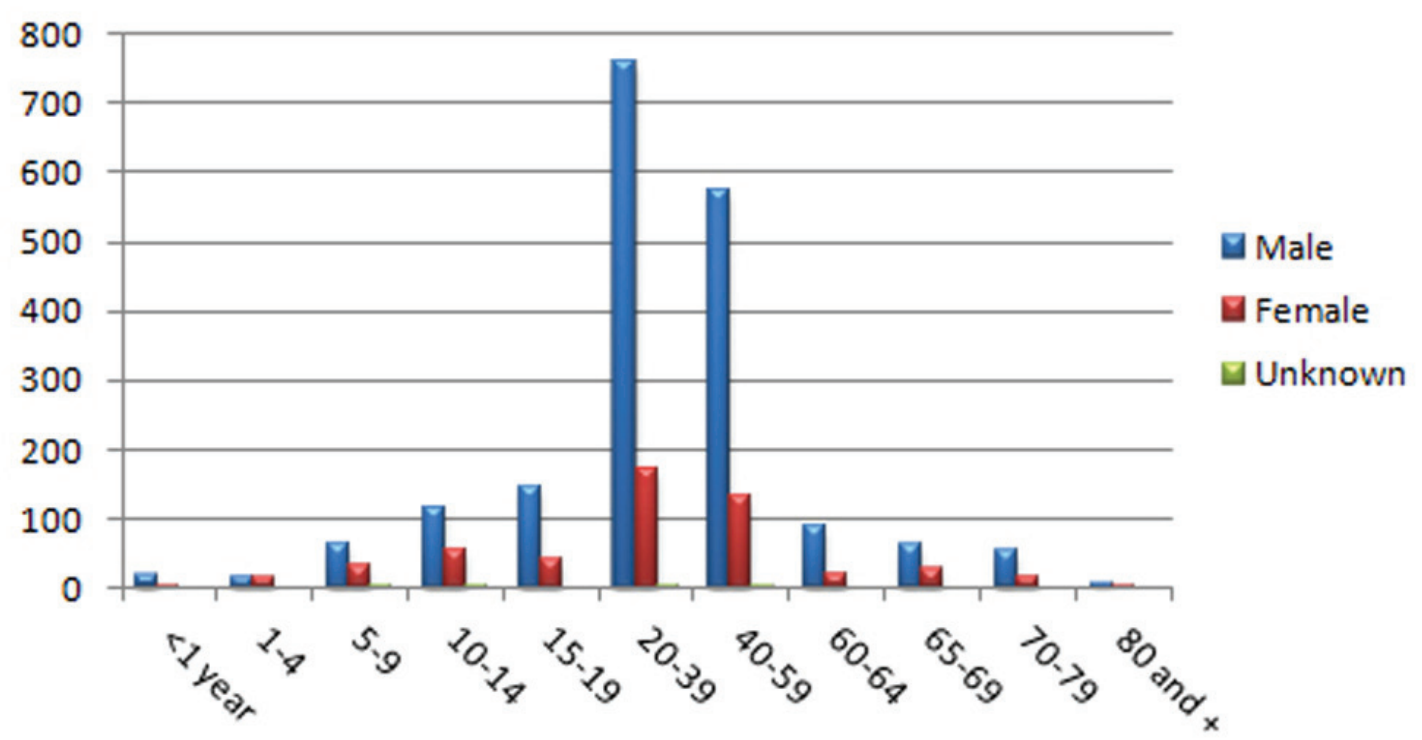

Figure 2. Frequency of snakebites by age group and gender in Rio de Janeiro state between 2001 and 2006 (source: MS/SVS/SINAN). 


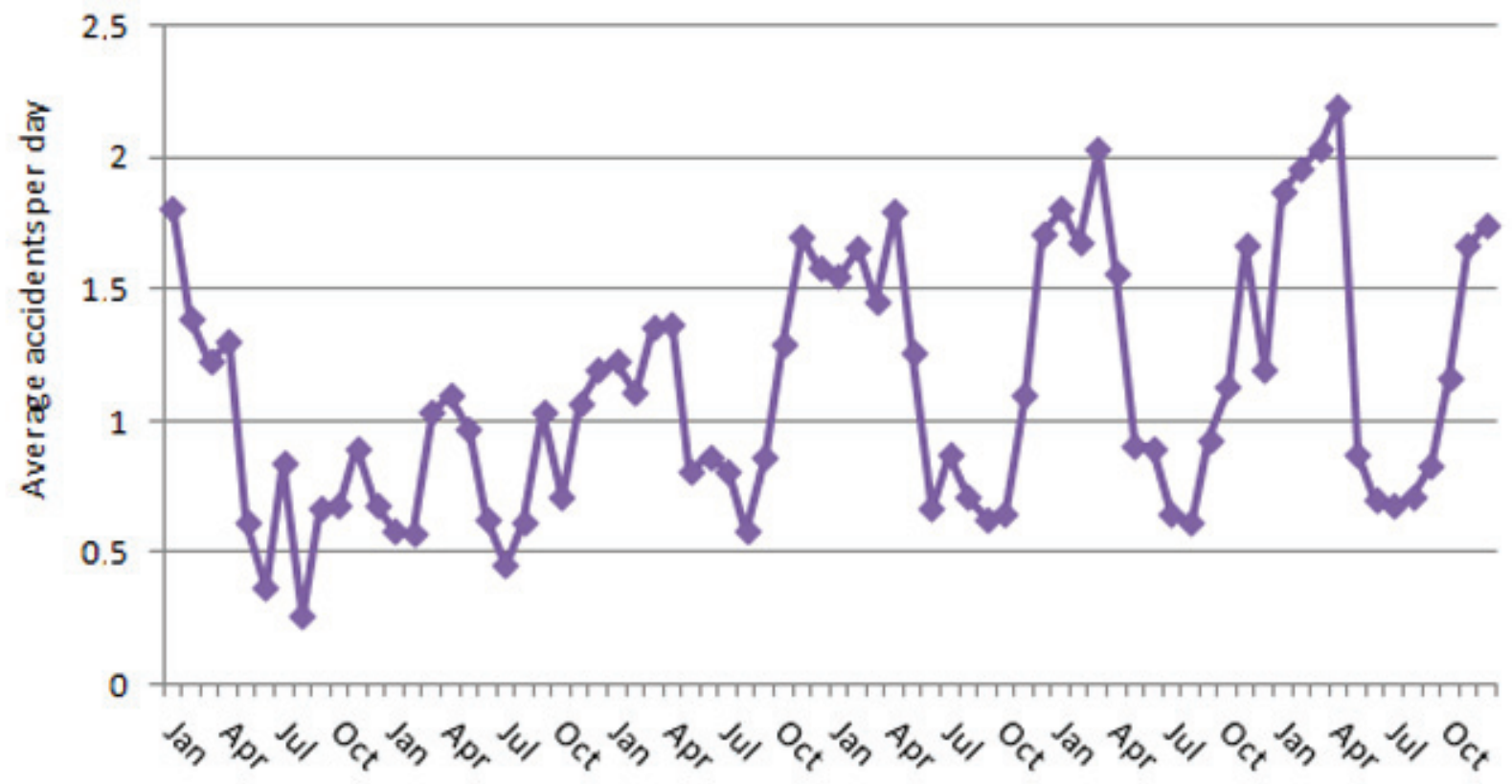

Figure 3. Monthly distribution of snakebite averages in Rio de Janeiro state between 2001 and 2006 (source: MS/SVS/SINAN).

dos Reis, Rio de Janeiro, Parati, Teresópolis, and Petrópolis. This can be explained by the concentration of population living in the capital, and by the concentrated area of natural forest in the other four municipalities. Municipalities with more than 50 accidents contained important conservation units (national and state parks), the natural habitat of most venomous snakes.

In the 20-59 year age group, the higher frequency of accidents in males $(81.3 \%)$ can be explained by occupation, as most accidents happened in rural areas where men work (2). Similar results for affected males were found in different states from different regions of Brazil, varying from $82.1 \%$ in the river Purus riverine community of Amazonas to $53.1 \%$ in the north of Minas Gerais state $(27,19)$. Albuquerque et al. (13) found that in Paraíba state $73.2 \%$ of victims were male. Another study on Bothrops snakebites in Paraíba state by Oliveira et al. (38) showed a $75.1 \%$ predominance of male victims in that region, following the national average.

The seasonal snakebite pattern in Rio de Janeiro state can be explained by the fact that snakes are ectothermic animals that need a high temperature for thermoregulation, which is fundamental for satisfactory metabolism. This same characteristic has been observed in the states of Goiás and São Paulo, and in the regions of northern Minas Gerais and city of Juiz de Fora $(27,30,32,36)$. In the Campina Grande region, Paraíba state, and the state of Ceará, the periods in which most accidents happened were from July to November and April to September, which is substantially different from the rest of the country $(28,31)$. Seasonal accident distribution has already been mentioned in several articles on ophidism in Brazil, mainly in the Amazon area $(22,23,29)$.

According to Lemos et al. (28), as far as the northeast is concerned, especially the countryside, there may be a direct relationship between the increasing number of accidents and harvest time, as well as the higher rainfalls in the area, characterizing them as work-related accidents. In fact, this increase coincides with the migration of rural workers to the fields. Knowledge on snake seasonality highlights the months in which there are higher risks of accidents. This is extremely important as it alerts healthcare providers, helps establish distribution strategies and control of antivenom stocks in health centers, and 
stimulates preventive education campaigns. In Rio de Janeiro state, $45.9 \%$ of the accidents caused by snakes during the study period were classified as minor. In the consulted literature, snakebite seriousness in Brazil is generally considered moderate, as in the states of Bahia and Goiás and the regions of Juiz de Fora (Minas Gerais state) and Rio Branco (Acre state), or minor, as in the regions of northern Minas Gerais, northwest São Paulo and Campina Grande (Paraíba state) (25, 27, 28, 30, 32, 34, 39).

Concerning snakebites, the time between bite and first aid is known to be crucial for optimal treatment outcome. Studies have shown that the average time between accident and first aid in Rio de Janeiro state is better than the time recommended by the Health Ministry to guarantee efficient treatment, below six hours (10). In this study, only $4.8 \%$ of the cases were actually treated six hours or later after the accident and almost all cases evolved to full cure.

In most Brazilian states, the average time between accident and first aid was below six hours. Only northern regions exceeded this Health Department recommended time, including Amapá, the riverine communities of the river Purus and other cities of Amazonas state, and some areas of Araguaia (Tocantins state) (22, $24,29,35)$. This delay in commencing first aid is probably due to the geographic configuration of these regions, and by the lack of transportation, often by boat or along difficult tracks. The situation for victims in Amazonas is more serious, since patients arrive at the hospital more than six hours after accidents and health professionals do not offer serotherapy. This practice has no scientific basis (22).

Of the 2,431 accidents in Rio de Janeiro, $14.6 \%$ were not classified regarding severity and the evolution was unknown or not recorded in $33.8 \%$. These data, and the fact that $83.0 \%$ of victims were medically treated in less than six hours, suggest adequate distribution of health centers providing serotherapy, and a possible substandard level of data recording.

It is important to highlight the problems found in recording snakebite information all over Brazil. Reports showing a lack of information about the identity of the snake causing the accident are common: for example, in the state of Paraíba, this information was missing in more than $29 \%$ of cases (13). Failures in recording antivenom administration were also observed as well as inappropriate application of anti-Crotalus antivenom in a case of Bothrops envenomation and antivenom application in non-venomous accidents $(25,30,34,35,39)$. Data available by SINAN do not allow us to evaluate similar parameters in this study.

Although our results show that the state of Rio de Janeiro has a good level of medical care, it could be improved by creating multidisciplinary teams with doctors, biologists, and nurses. The Vital Network for Brazil creates a stimulating environment for conducting this training, with both traditional and distance learning courses (41). The number of training hours must be increased to improve the skills of the professional teams responsible for victim care.

\section{ACKNOWLEDGEMENTS}

The authors thank Dr. Antonio Joaquim Werneck de Castro and Luis Eduardo Ribeiro da Cunha of Vital Brazil Institute for providing the necessary facilities, and are also grateful to post-graduation program in Information and Communication in Health (PPGICS) of Fiocruz.

\section{COPYRIGHT}

(C) CEVAP 2012

\section{SUBMISSION STATUS}

Received: December 15, 2011.

Accepted: March 5, 2012.

Abstract published online: March 6, 2012.

Full paper published online: May 31, 2012.

\section{CONFLICTS OF INTEREST}

The authors declare no conflicts of interest.

\section{ETHICS COMMITTEE APPROVAL}

This study was approved by the Ethics Committee on Human Research, Joaquim Venancio Polytechnic Health School, Fiocruz (protocol number 2011/0128).

\section{CORRESPONDENCE TO}

Claudio Machado, Instituto Vital Brasil, Rua Maestro José Botelho, 64, Niterói, RJ, 24230-410, Brazil. Phone: +55 2127119223 or +55 212711 9254. Email: herpetologia@ivb.rj.gov.br. 


\section{REFERENCES}

1. Fan HW, Cardoso JLC. Clinical toxicology of snake bites in South America. In: Meier J, White J, editors. Handbook of clinical toxicology of animal venoms and poisons. Florida: CRC Press; 1995. 667-88 p.

2. Gutierrez JM. Clinical toxicology of snake bites in Central America. In: Meier J, White J, editors. Handbook of clinical toxicology of animal venoms and poisons. Florida: CRC Press; 1995. 645-65 p.

3. Chippaux JP. Snake-bites: appraisal of the global situation. Bull World Health Organ. 1998;76(5):51524.

4. Warrell DA. Epidemiology, clinical features and management of snake bites in Central and South America. In: Campbell J, Lamar WW, editors. Venomous reptiles of the Western Hemisphere. Ithaca: Cornell University Press; 2004. 709-61 p.

5. Arfaoui A, Hmimou R, Ouammi L, Soulaymani A, Mokhtari A, Chafiq F, et al. Epidemiological profile of snakebites in Morocco. J Venom Anim Toxins incl Trop Dis. 2009;15(4):653-66.

6. Cesaretli Y, Ozkan O. Snakebites in Turkey: epidemiological and clinical aspects between the years 1995 and 2004. J Venom Anim Toxins incl Trop Dis. 2010;16(4): 579-86.

7. Chippaux JP. Control of ophidism in Brazil: a model for Africa. J Venom Anim Toxins incl Trop Dis. 2010;16(2):188-90.

8. Snake bite: time to stop the neglect. Lancet. 2010;375(9708):2.

9. Warrell AD. Snake bite. Lancet. 2010;375(9708):77-88.

10. Brasil. Ministério da Saúde. Secretaria de Vigilância em Saúde. Departamento de Vigilância Epidemiológica. Doenças infecciosas e parasitárias: guia de bolso. 8th ed. Brasília: Ministério da Saúde; 2010. 444 p.

11. Lira-da-Silva RM, Mise YF, Brasil TK, Casais-e-Silva, LL, Carvalho FM. Morbimortalidade por ofidismo no Nordeste do Brasil (1999 - 2003). Gaz Méd Bahia. 2009;79(Supl 1):21-5.

12. Araújo FAA, Santalúcia M, Cabral R. Epidemiologia dos acidentes por animais peçonhentos. In: Cardoso JLC, França FOS, Fan HW, Malaque CMS, Haddad V Jr, editors. Animais peçonhentos no Brasil: biologia, clínica e terapêutica dos acidentes. 1st ed. São Paulo: Sarvier; 2003. 6-12 p.

13. Albuquerque HN, Fernandes A, Albuquerque ICS. Snakebites in Paraíba, Brazil. J Venom Anim Toxins incl Trop Dis. 2005;11(3):242-51.

14. Kasturiratne A, Wickremasinghe AR, Silva N, Gunawardena NK, Pathmeswaran A, Premaratna $\mathrm{R}$, et al. The Global Burden of snakebite: a literature analysis and modelling based on regional estimates of envenoming and deaths. PLoS Med. 2008;5(11):e218.

15. Bochner R, Struchiner CJ. Epidemiologia dos acidentes ofídicos nos últimos 100 anos no Brasil: uma revisão. Cad Saúde Pública. 2003;19(1):7-16.

16. Penteado DC. Accidentes ophidicos: effeitos do tratamento específicos sobre a mortalidade ophídica. In: Coletânea de trabalhos do Instituto Butantan
(1901-1917). São Paulo: Instituto Butantan; 1918. p. 325-31.

17. Amaral A. Campanhas anti-ophidicas. Mem Inst Butantan. 1930;5(1):195-232.

18. Barroso RD. Ofidismo no Brasil: considerações em torno de 2.238 acidentes ofídicos tratados com soro. Bol Inst Vital Brazil. 1944;26(1):35-47.

19. Fonseca F. Animais peçonhentos. São Paulo: Empresa Gráfica da Revista dos Tribunais/Instituto Butantan; 1949. 376 p.

20. Martinez EG, Vilanova MCT, Jorge MT, Ribeiro LA. Aspectos epidemiológicos do acidente ofídico no Vale do Ribeiro, São Paulo, 1985 a 1989. Cad Saúde Pública. 1995;11(3):511-5.

21. Da Silva ERO, Lofego AC. Acidentes ofídicos na região de São José do Rio Preto (SP). Revista UNORP. 2005;4(12):128-33.

22. Borges CC, Sadahiro M, Santos MC. Aspectos epidemiológicos e clínicos dos acidentes ofídicos ocorridos nos municípios do Estado do Amazonas. Rev Soc Bras Med Trop. 1999;32(6):637-46.

23. Pardal PPO, Monteiro MRCC, Arnaund RN, Lopes FOB, Asano ME. Aspectos epidemiológicos de 465 acidentes ofídicos atendidos no HUJBB - Belém - Pará no período de 1993 a 1994. Rev Soc Bras Med Trop. 1995;28(Supl 1):170.

24. Paula Neto JB, Ribeiro RSP, Luz JA, Galvão M, Carvalho SMD, Haddad V Jr. Clinical and epidemiological characteristics of injuries caused by venomous snakes observed at the hospital for tropical diseases of Araguaína, Tocantins State, Brazil, from 1995 to 2000. J Venom Anim Toxins incl Trop Dis. 2005;11(4):42232.

25. Rojas CA, Gonçalves MR, Almeida Santos, SM. Epidemiologia dos acidentes ofídicos na região noroeste do Estado de São Paulo, Brasil. Rev Bras Saúde Prod An. 2007;8(3):193-204.

26. Hote PS, Silva DJS, Roberti HM, Povoa HCC. Estudo epidemiológico dos acidentes por serpentes do gênero Bothrops na região de Muriaé. In: III Encontro de Iniciação Científica da FAMINAS zona da mata, 2006, Muriaé. Anais do III Encontro de Iniciação Científica da FAMINAS zona da mata. Muriaé: Editora FAMINAS; 2006. 207 p. 3 vol.

27. Lima JS, Martelli Junior H, Martelli DRB, Silva MS, Carvalho SFG, Canela JR, et al. Perfil dos acidentes ofídicos no norte do Estado de Minas Gerais, Brasil. Rev Soc Bras Med Trop. 2009;42(5):561-4.

28 Lemos JC, Almeida TD, Fook SM, Paiva AA, Simões, MOS. Epidemiologia dos acidentes ofídicos notificados pelo Centro de Assistência e Informação Toxicológica de Campina Grande (Ceatox-CG), Paraíba. Rev Bras Epidemiol. 2009;12(1):50-9.

29. Waldez F, Vogt RC. Aspectos ecológicos e epidemiológicos de acidentes ofídicos em comunidades ribeirinhas do baixo rio Purus, Amazonas, Brasil. Acta Amaz. 2009;39(3):681-92.

30. Barreto BB, Santos PLC, Martins FJ, Barbosa NR, Ribeiro LC, Leite ICG, et al. Perfil epidemiológico dos acidentes ofídicos no município de Juiz de Fora - MG no período de 2002-2007. Rev APS. 2010;13(2):190-5. 
31. Feitosa RF, Melo IM, Monteiro HS. Epidemiologia dos acidentes por serpentes peçonhentas no Estado do Ceará - Brasil. Rev Soc Bras Med Trop. 1997;30(4):295301.

32. Pinho FMO, Oliveira ES, Faleiros F. Acidente ofídico no Estado de Goiás. Rev Assoc Med Bras. 2004;50(1):936.

33. Vilar JC, Carvalho CM, Furtado MFD. Epidemiologia dos acidentes ofídicos em Sergipe (1999-2002). Biol Geral Exper. 2004;4(2):3-13.

34. Moreno E, Queiroz-Andrade M, Lira-da-Silva RM, Tavares-Neto J. Características clínicoepidemiológicas dos acidentes ofídicos em Rio Branco, Acre. Rev Soc Bras Med Trop. 2005;38(1):15-21.

35. Lima ACSF, Campos CEC, Ribeiro JR. Perfil epidemiológico de acidentes ofídicos do Estado do Amapá. Rev Soc Bras Med Trop. 2009;42(3):329-35.

36. Ribeiro LA, Albuquerque MJ, Pires de Campos VAF, Katz G, Takaoka NY, Lebrão ML, et al. Óbitos por serpentes peçonhentas no Estado de São Paulo: avaliação de 43 casos, 1988/93. Rev Ass Med Brasil. 1998;44(4):312-8.

37. Nascimento SP. Aspectos epidemiológicos dos acidentes ofídicos ocorridos no Estado de Roraima, Brasil, entre 1992 e 1998. Cad Saúde Pública. 2000;16(1):271-6.
38. Oliveira FN, Brito MT, Morais ICO, Fook SML, Albuquerque HN. Accidents caused by Bothrops and Bothropoides in the State of Paraíba: epidemiological and clinical aspects. Rev Soc Bras Med Trop. 2010;43(6):662-7.

39. Mise YF, Lira-da-Silva RM, Carvalho FM. Envenenamento por serpentes do gênero Bothrops no Estado da Bahia: aspectos epidemiológicos e clínicos. Rev Soc Bras Med Trop. 2007;40(5):569-73.

40. Rodrigues CK, Koch MC, Sgrott I, Mello FM, Grando M, Zannin M. Aspectos clínicos epidemiológicos dos acidentes por Micrurus registrados no CIT/SC. In:Reunião Anual da SBPC, 58a , 2006, Florianópolis Santa Catarina: Universidade Federal de Santa Catarina; 2006.

41. Brazil TK, Melgarejo AR, Werneck de Castro AJ, Barraviera B, Souza CM, Brazil EV, et al. Vital network for Brazil: national network of information, discussion and cooperation concerning venomous animals. J Venom Anim Toxins incl Trop Dis. 2011;17(3):235-6. 